\title{
THE EFFECTS OF LEACHING ON THE MINERAL PHASES IN ARGON-OXYGEN DECARBURIZATION OF STAINLESS-STEEL SLAG
}

\author{
VPLIV JEDKANJA NA MINERALNE FAZE ŽLINDRE, NASTALE \\ MED AOD-OBDELAVO NERJAVNEGA JEKLA
}

\author{
Ya-Jun Wang ${ }^{1,2}$, Ya-Nan Zeng ${ }^{1 *}$, Jun-Guo Li ${ }^{1}$ \\ ${ }^{1}$ School of Metallurgy and Energy, North China University of Science and Technology, 063009 Tangshan, P. R. China \\ ${ }^{2}$ School of Materials and Metallurgy, Northeastern University, 110819 Shenyang, P. R. China
}

Prejem rokopisa - received: 2019-10-31; sprejem za objavo - accepted for publication: 2020-02-12

doi:10.17222/mit.2019.262

\begin{abstract}
The major mineral compositions of an original argon-oxygen decarburization (AOD) slag, a natural leaching residue, an acid-leaching residue and an alkaline leaching residue were analyzed using X-ray diffraction. The volume percentages and microstructures of the main phases in the original slag and the leaching residues were observed using mineral microscopy. The results show that the main phases in the AOD slag were dicalcium silicate $\left(C_{2} S\right)$, merwinite $\left(C_{3} M_{2}\right)$, pyroxene and rankinite; the volume percentages of the main mineral phases during leaching were changed. In the natural leaching residue and acid-leaching residue, the amount of $\mathrm{C}_{2} \mathrm{~S}$ decreased, and the contents of rankinite, pyroxene and $\mathrm{C}_{3} \mathrm{MS}_{2}$ increased compared with those in the original slag. In the alkaline leaching residue, the change in the volume percentages of the major mineral phases was very small. In the original slag, $\mathrm{C}_{2} \mathrm{~S}$ mainly existed as fine-grained aggregates and columns with relatively coarse grain sizes. In the neutral leaching residue and acid-leaching residue, $\mathrm{C}_{2} \mathrm{~S}$ had short columnar and fine acicular shapes and a small particle size. The particle sizes of the other mineral phases in the neutral and acid-leaching residues, such as $\mathrm{C}_{3} \mathrm{MS}_{2}$, rankinite, and pyroxene, increased. The morphology and volume percentage of the minerals in the alkaline leaching residue were similar to those in the original residue. It was concluded that the main cause of the above phenomena was the hydration of $\mathrm{C}_{2} \mathrm{~S}$ and the insolubility of rankinite in water, which resulted in the formation of $\mathrm{C}_{3} \mathrm{MS}_{2}$.
\end{abstract}

Keywords: AOD slag, mineral composition, microstructure, dissemination characteristics, leaching

Avtorji tega prispevka so z rentgensko difrakcijo (XRD) analizirali mineralno sestavo žlindre nastale med konvertersko obdelavo (razogljičenjem) jekla z argonom in kisikom (AOD). Pri tem so analizirali naravne, kisle in alkalne ostanke jedkanja. Volumski deleži in mikrostrukture glavnih faz v originalni žlindri in ostanke jedkanja so opazovali pod mineraloškim mikroskopom. Rezultati analiz so pokazali da so glavne faze v AOD-žlindri dikalcijev silikat $\left(\mathrm{C}_{2} \mathrm{~S}\right)$, mervinit $\left(\mathrm{C}_{3} \mathrm{MS}_{2}\right)$, piroksen in rankinit. Volumski deleži glavnih mineralnih faz so se med jedkanjem spremenili. V naravnih ostankih jedkanja s kislino se je vsebnost $\mathrm{C}_{2} \mathrm{~S}$ zmanjšala, povečale pa so se vsebnosti rankinita, piroksena in $\mathrm{C}_{3} \mathrm{MS}_{2} \mathrm{v}$ primerjavi s tistimi $\mathrm{v}$ originalni žlindri. Spremembe volumskega deleža glavnih faz v ostankih alkalnega jedkanja (luženja) pa so bile zelo majhne. V originaln žlindri je bil $\mathrm{C}_{2} \mathrm{~S} v$ glavnem prisoten $\mathrm{v}$ obliki finozrnatih agregatov in relativno grobo zrnatih stebričkov. Pri neutralnem in kislem jedkanju je imel $\mathrm{C}_{2} \mathrm{~S}$ majhne stebričasto in drobno igličasto oblikovane delce. Velikost delcev ostalih glavnih mineralnih faz kislih in alkalnih ostankov, kot so $\mathrm{C}_{3} \mathrm{MS}_{2}$ rankinit in piroksen pa se je povečala. Morfologija in volumski delež mineralov v alkalnih ostankih sta bila podobna originalnim ostankom. Avtorji zaključujejo, da je glavni razlog za zgoraj navedene pojave hidracija $\mathrm{C}_{2} \mathrm{~S}$ in netopnost rankinita v vodi, rezultat katerega je tvorba $\mathrm{C}_{3} \mathrm{MS}_{2}$.

Ključne besede: AOD-žlindra, mineralna sestava, mikrostruktura, karakteristike razkroja, jedkanje

\section{INTRODUCTION}

Stainless-steel slag (SSS) is a byproduct of stainless-steel smelting. The crude stainless-steel output in China was 26.71 million tons in $2018,{ }^{1}$ corresponding to the production of approximately 6 million tons of SSS. ${ }^{2}$ Due to the smelting process, SSS mainly includes electric arc furnace (EAF) slag and argon-oxygen decarburization (AOD) slag. SSS is an alkaline slag containing a large amount of alkali metal elements, such as $\mathrm{Ca}$ and $\mathrm{Mg}$, and silicate phases are the predominant mineral phases. ${ }^{3,4}$ It is generally accepted that the silicate phases typically found in SSS comprise tricalcium silicate $\left(3 \mathrm{CaO} \cdot \mathrm{SiO}_{2}\right)$, gamma dicalcium silicate $\left(\gamma-2 \mathrm{CaO} \cdot \mathrm{SiO}_{2}\right)$,

*Corresponding author's e-mail:

zengyanann@126.com (Ya-Nan Zeng) merwinite $\left(\mathrm{Ca}_{3} \mathrm{Mg}\left(\mathrm{SiO}_{4}\right)_{2}\right)$, and bredigite $\left(\mathrm{Ca}_{7} \mathrm{Mg}\right.$ $\left.\left(\mathrm{SiO}_{4}\right)_{4}\right)$. $^{5-9}$

During the stainless-steel smelting process, a certain amount of chromium in the molten steel can be oxidized due to oxygen decarburization, and chromium-containing SSS is produced. Chromium is mainly trivalent in SSSs, but it can be converted to $\mathrm{Cr}(\mathrm{VI})$ and released into the environment under suitable conditions. ${ }^{10-12} \mathrm{Cr}(\mathrm{VI})$ can induce toxic and carcinogenic effects through a complex combination of mechanisms, including oxidative stress, epigenetic changes, chromosome and DNA damage, and mutagenesis. ${ }^{13}$ As a result, SSSs cannot be re-used directly, like ordinary steel slags. Q. Shu ${ }^{14}$ and L. H. $\mathrm{CaO}^{15}$ studied the behavior of chromium in SSSs and found that chromium was mainly present in the spinel phase, while other silicate phases (i.e., the glass, 
dicalcium silicate, rhodonite, and feldspar phases) also acted as solvents for a small amount of chromium. Y. Samade ${ }^{16}$ and G. Adegoloye ${ }^{17}$ found that when the $\mathrm{C}_{2} \mathrm{~S}$ phase acted as a solvent for chromium, chromium leachability was dramatically improved, while the spinel phase was a nonhydrolyzable phase that sealed the chromium. L. H. $\mathrm{CaO}^{18}$ analyzed the behavior of chromium in SSSs using thermodynamic calculations and experiments and found that the glass, dicalcium silicate, rhodonite, and feldspar phases had leaching risks, while the chromium in the spinel phase was stable.

Although the content of chromium solutes in the $\mathrm{C}_{2} \mathrm{~S}$ mineral phase is relatively low, rain can cause dissolution and leaching, making this phase a potential source for chromium release into the environment. M. Kuhn ${ }^{19}$ associated chromium leaching with the content of spinel minerals in SSSs and constructed a corresponding evaluation factor referred to as $\mathrm{sp}(\mathrm{sp}=0.2 \mathrm{MgO}+$ $1.0 \mathrm{Al}_{2} \mathrm{O}_{3}+\mathrm{nFeO}_{\mathrm{x}}-0.5 \mathrm{Cr}_{2} \mathrm{O}_{3}$ ); furthermore, it was found that $\mathrm{sp}>5$ promotes the formation of spinels and inhibits the leaching of chromium. Q. Wang ${ }^{20}$ determined that mineral phases should influence the release capacity and leaching speciation of chromium from slag. The original phases of $\mathrm{Cr}_{2} \mathrm{O}_{3}$ in AOD slag are very important and impact on potential chromium release. ${ }^{21}$

Mineral characterization of SSSs is the first step in disposal and utilization. It is necessary to study the change rules of mineral phases in SSSs during different leaching processes. In the current literature, research on leaching characteristics does not include systematic studies of the effect of leaching on the mineral phases in SSSs. In this study the mineralogical properties of original AOD slag and leaching residues were studied. These properties include the chemical composition, mineral identity, volume percentage, and mineral morphology.

\section{EXPERIMENTAL PART}

\subsection{Materials}

The collected original AOD slag was powdery and had a small particle size after the air-cooling and water-spraying processes. The original slag was dried for $6 \mathrm{~h}$ at $105^{\circ} \mathrm{C}$ to remove the free moisture that was adsorbed during the cooling treatment. The element composition of the AOD slag was determined by inductively coupled plasma mass spectrometry (ICP-MS), and it was found that the AOD slag comprised several oxides (Table 1).

Samples comprising $3 \times 10 \mathrm{~g}$ of the dried AOD original slag were placed in $3 \times 250 \mathrm{~mL}$ conical flasks. Next, $100 \mathrm{~mL}$ of distilled water was added to every flask and the $\mathrm{pH}$ of the three solution systems was adjusted to 3.0, 7.0, and 9.0. The flasks were capped and placed in a shaker bath for 10 days at a constant temperature. Then, the samples were retrieved, and the moisture was removed in a drying oven at $105^{\circ} \mathrm{C}$ for $6 \mathrm{~h}$. The samples were then stored and denoted acid-leaching residue, neutral leaching residue, and alkaline leaching residue, respectively.

The original slag, acid-leaching residue, neutral leaching residue, and alkaline leaching residue were sieved with a $48 \mathrm{~mm}$ (300 mesh) sieve. The undersized slag particles were used for the mineralogical analysis.

\subsection{Mineralogical identification}

The mineralogical compositions of the original AOD slag, acidic-leaching residue, neutral leaching residue, and alkaline leaching residue were determined by X-ray diffraction (XRD). The measurements were performed on a D/MAX2500PC automatic diffractometer with a continuous scanning device using $\mathrm{Cu}-K \alpha$ radiation at $100 \mathrm{~mA}$ and $40 \mathrm{kV}$ and a scanning velocity of $10^{\circ}$ $2 \theta / \mathrm{min}$.

\subsection{Microstructure analysis}

The volume percentage, microstructures, and dissemination characteristics of the minerals in the original slag, acid-leaching residue, neutral leaching residue, and alkaline leaching residue were observed and statistically analyzed using a biased/reversed mineral microscope (Axioskop 40, Carl Zeiss AG).

\section{RESULTS AND DISCUSSION}

\subsection{Mineral composition of AOD slag}

As shown in Table 1, the major components in the AOD slag were $\mathrm{CaO}(55.90 \%)$ and $\mathrm{SiO}_{2}(24.67 \%)$. $\mathrm{MgO}(5.85 \%)$ was the third-most prevalent oxide. Small amounts of $\mathrm{Al}_{2} \mathrm{O}_{3}, \mathrm{Cr}_{2} \mathrm{O}_{3}, \mathrm{FeO}, \mathrm{MnO}$, and $\mathrm{TiO}_{2}$ were contained in the AOD slag.

AOD slag is an alkaline waste with a binary alkalinity $\left(\mathrm{CaO} / \mathrm{SiO}_{2}\right)$ of 2.27 and is classified as a highalkalinity steel slag. Therefore, the predominant ore phases in the AOD slag are the $\mathrm{C}_{2} \mathrm{~S}, \mathrm{C}_{3} \mathrm{~S}$ and $\mathrm{RO}$ phases. ${ }^{22}$ The leaching process can alter the composition of mineral phases in the AOD slag.

The various crystalline minerals in the slag had unique crystal-structure parameters, such as lattice type, cell size, atomic number, and the positions of the atoms in the unit cell. XRD indicates the crystallographic phases that are present. Hence, the main mineral phases contained in the original slag and three types of residue

Table 1: Chemical composition of AOD slag (w/\%)

\begin{tabular}{|c|c|c|c|c|c|c|c|c|}
\hline Components & $\mathrm{CaO}$ & $\mathrm{SiO}_{2}$ & $\mathrm{MgO}$ & $\mathrm{Al}_{2} \mathrm{O}_{3}$ & $\mathrm{Cr}_{2} \mathrm{O}_{3}$ & $\mathrm{FeO}$ & $\mathrm{MnO}$ & $\mathrm{TiO}_{2}$ \\
\hline Content & 55.90 & 24.67 & 5.85 & 1.07 & 0.51 & 1.15 & 0.16 & 0.88 \\
\hline
\end{tabular}




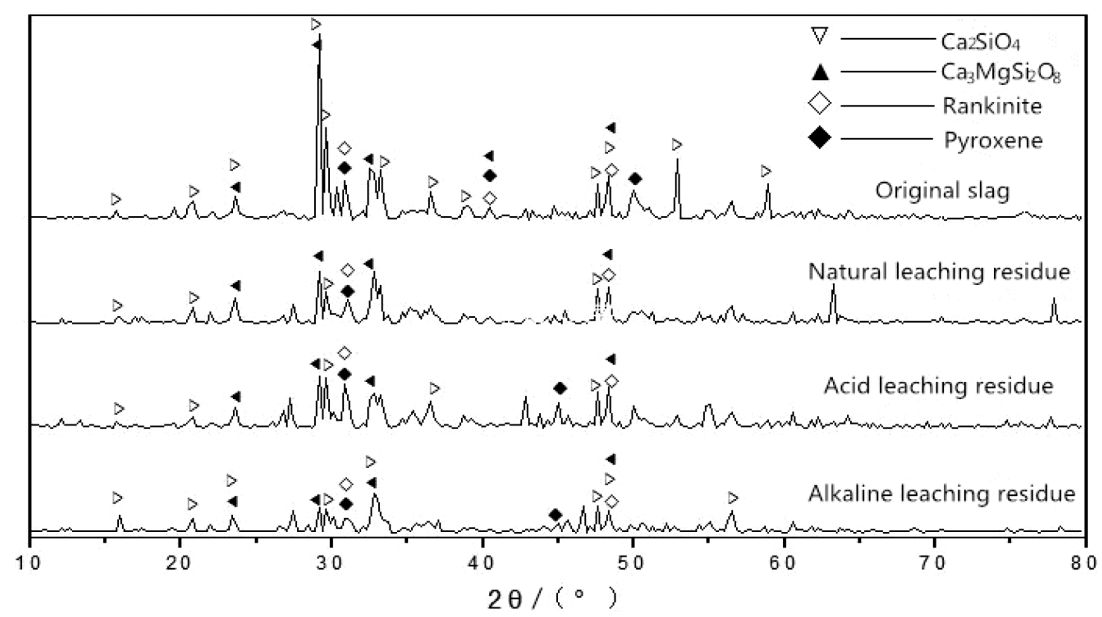

Figure 1: XRD patterns of the original and residual AOD slags

were analyzed by XRD. The diffraction patterns are shown in Figure 1.

As shown in Figure 1, the main mineral phases in the original AOD slag were $\mathrm{C}_{2} \mathrm{~S}, \mathrm{C}_{3} \mathrm{~S}$, pyroxene and rankinite, which corresponded to the results of studies by B. Liu et al., J. G. $\mathrm{Li}^{23,24}$ and C. L. Zhen et al. ${ }^{25}$ The leaching process altered the mineral composition of the AOD slag. The three kinds of leaching residue had diffraction peaks corresponding to the above-mentioned main phases; the peak positions were coincident, but the intensity changed greatly. After neutral and acid leaching, the solid-solution peaks of $\mathrm{C}_{2} \mathrm{~S}$ and $\mathrm{C}_{3} \mathrm{MS}_{2}(2 \theta$ $=29.09^{\circ}$ ) were significantly reduced, and the $C_{2} S$ peak disappeared. The $\mathrm{C}_{3} \mathrm{MS}_{2}$ peak $\left(2 \theta=32.765^{\circ}\right)$ intensity significantly increased. Furthermore, the peak intensity of rankinite in the neutral leaching residue increased. After alkaline leaching, the peak positions of the main minerals remained basically unchanged, but the peak intensity and peak width were greatly changed.

These observations show that after the AOD slag experienced neutral, acid, and alkaline leaching, the mineral-phase species varied little, but the leaching process had a great effect on the relative content of each mineral phase. Additionally, from the XRD patterns, it can be seen that the peak height and peak width of each ore phase at the corresponding positions (2 $\theta$ ) changed, which indicates that the crystal phases of the AOD slag minerals were transformed during the leaching process.

\subsection{Mineral content in the AOD slag}

The volume percentages of the representative minerals in the four types of samples were calculated with mineral microscopy. The results are shown in Table 2.

The statistical results confirmed the above XRD analysis results. After leaching, the principal mineralphase compositions were identical, but the mineralvolume percentages changed greatly.

$\mathrm{C}_{2} \mathrm{~S}$ was the predominant mineral phase in the original AOD slag. The volume percentage of $\mathrm{C}_{2} \mathrm{~S}$ decreased from $80 \%$ to $40 \%$ and $50 \%$ after neutral leaching and acid leaching, respectively, due to the hydration reaction of $\mathrm{C}_{2} \mathrm{~S}$, which is given as Equation 1. The volume percentage of $\mathrm{C}_{3} \mathrm{MS}_{2}$ significantly increased after neutral leaching and acid leaching, from $5 \%$ to $7 \%$ to above $40 \%$. This increase occurred because when a highly saturated $\mathrm{CaO}$ compound is present in slag, if $\mathrm{MgO}$ is present in a free state, then $\mathrm{C}_{3} \mathrm{MS}_{2}$ may be formed; this process is described by Equation 2.

The content of rankinite in the residue after neutral leaching increased from $3 \%$ to $5 \%$ to $12 \%$ to $15 \%$. This increase occurred because the dehydration of C-S-H gel can form rankinite, as shown by Equation 3. Acid-leaching solutions can damage C-S-H gel, so the volume percentage of rankinite in the acid-leaching residue decreased greatly compared with that of the neutral leaching residue.

Since $\mathrm{OH}^{-}$has an inhibitory effect on the hydrolysis of $\mathrm{C}_{2} \mathrm{~S}$, the volume percentage of $\mathrm{C}_{2} \mathrm{~S}$ and $\mathrm{C}_{3} \mathrm{MS}_{2}$ in the alkaline leaching residue had almost no change.

Table 2: Phase composition of the original AOD slag and leaching residues (volume \%)

\begin{tabular}{|l|c|c|c|c|c|c|c|c|c|c|}
\hline \multicolumn{1}{|c|}{ Mineral } & $\mathrm{C}_{2} \mathrm{~S}$ & $\mathrm{C}_{3} \mathrm{MS}_{2}$ & Pyroxene & Rankinite & Spinel & Fe & Magnetite & Golgi- rich & Glass & RO \\
\hline Original & $80-85$ & $5-7$ & $2-3$ & $3-5$ & Little & $1-2$ & Little & Trace & Trace & Trace \\
\hline Neutral & $35-40$ & $40-45$ & $3-5$ & $12-15$ & $1-2$ & $1-2$ & Little & - & - & - \\
\hline Acid & $40-45$ & $50-55$ & Little & $1-2$ & - & $1-2$ & Trace & Trace & Trace & Trace \\
\hline Alkaline & $85-90$ & $5-7$ & $1-2$ & $1-2$ & - & $1-2$ & Little & - & - & - \\
\hline
\end{tabular}




$$
\begin{aligned}
& 2\left(2 \mathrm{CaO} \cdot \mathrm{SiO}_{2}\right)+4 \mathrm{H}_{2} \mathrm{O}= \\
& =3 \mathrm{CaO} \cdot 2 \mathrm{SiO}_{2} \cdot 3 \mathrm{H}_{2} \mathrm{O}+\mathrm{Ca}(\mathrm{OH})_{2} \\
& 3 \mathrm{CaO} \cdot 2 \mathrm{SiO}_{2} \cdot 3 \mathrm{H}_{2} \mathrm{O}+\mathrm{MgO}=\mathrm{Ca}_{3} \mathrm{MgSi}_{2} \mathrm{O}_{8}+3 \mathrm{H}_{2} \mathrm{O} \\
& 3 \mathrm{CaO} \cdot 2 \mathrm{SiO}_{2} \cdot 3 \mathrm{H}_{2} \mathrm{O}=3 \mathrm{CaO} \cdot 2 \mathrm{SiO}_{2}+3 \mathrm{H}_{2} \mathrm{O}
\end{aligned}
$$

Similar to those in the original slag, the contents of the Golgi-rich phase, the glass phase, the RO phase, and calcium ferrite in the leaching residues were very small. In light of the errors due to slag collection, sample preparation, and the experimental procedure, these components were ignored here.

\subsection{Dissemination characteristics of minerals in the original AOD slag}

The characteristics of typical minerals in the original AOD slag are shown in Figure 2. $\mathrm{C}_{2} \mathrm{~S}$ (A) had different particle sizes and mainly existed as fine-grained aggregates $(0.01$ to $0.1 \mathrm{~mm})$ and columns $(0.01 \times 0.12$ $\mathrm{mm}$ to $0.08 \times 0.27 \mathrm{~mm}), \mathrm{C}_{2} \mathrm{~S}$ was brownish black with high protuberances, its interference color was primary gray, and its extinction angle was large. $\mathrm{C}_{3} \mathrm{MS}_{2}$ (B) existed mainly as granules, small spindles, and short columns with particle sizes between $0.03 \mathrm{~mm}$ and $0.25 \mathrm{~mm} . \mathrm{C}_{3} \mathrm{MS}_{2}$ was colorless with high protuberances, its highest interference color was grade-1 red, and its extinction angle was small. Double crystals were visible in $\mathrm{C}_{3} \mathrm{MS}_{2}$.

In addition, there were other minerals with low volume percentages in the slag sample. Pyroxene $\left(\mathrm{C}_{1}\right.$, $\mathrm{C}_{2}$ ) mainly existed as granules $(0.03 \mathrm{~mm}$ to $0.25 \mathrm{~mm})$ and was light green and colorless, and its interference color was secondary blue. Tetralite mainly existed as shaped crystals and small columns and was colorless, and its interference color was grade 1 gray. The spinel phase existed mainly as quadrilaterals, granular regions and very small granules $(0.005 \mathrm{~mm}$ to $0.03 \mathrm{~mm})$. Fe existed mainly as granules $(0.01 \mathrm{~mm}$ to $0.1 \mathrm{~mm})$ and was mostly distributed in $\mathrm{C}_{2} \mathrm{~S}$ and partially distributed with magnetite, and a small amount existed in monomeric form. Magnetite existed mainly as granules $(0.01 \mathrm{~mm}$ to $0.03 \mathrm{~mm}$ ).

Several complete residues (D) were found under the microscope. The main minerals comprised $\mathrm{C}_{2} \mathrm{~S}$, calcium ferrite, Golgi-rich phases, glassy phases and RO phases.

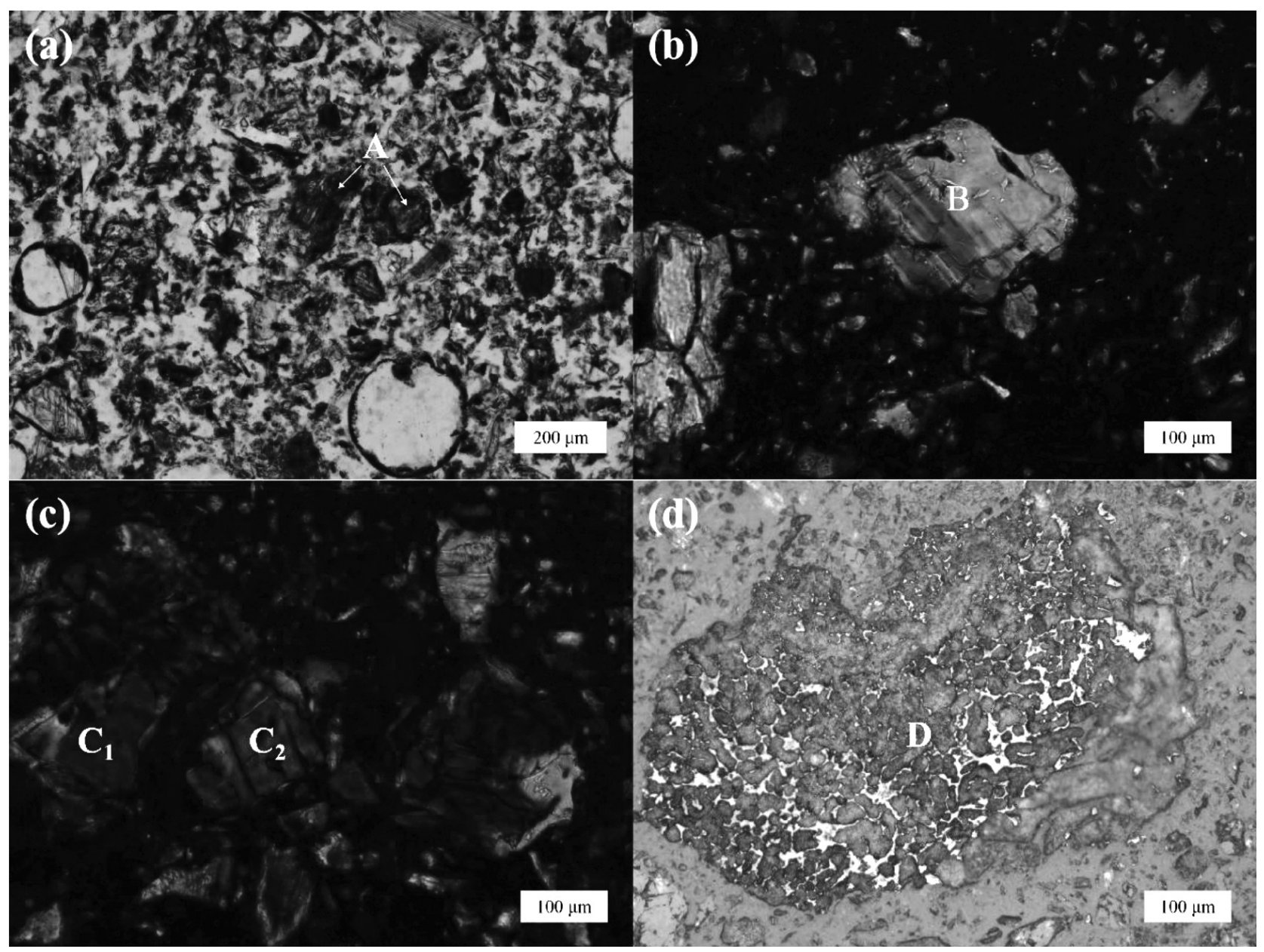

Figure 2: Microscopic structure of the original AOD slag: a) $\mathrm{C}_{2} \mathrm{~S}$ under transmitted light, b) $\mathrm{C}_{3} \mathrm{MS}_{2}$ under transmitted light, c) pyroxene under transmitted light, d) complete slag under reflected light 


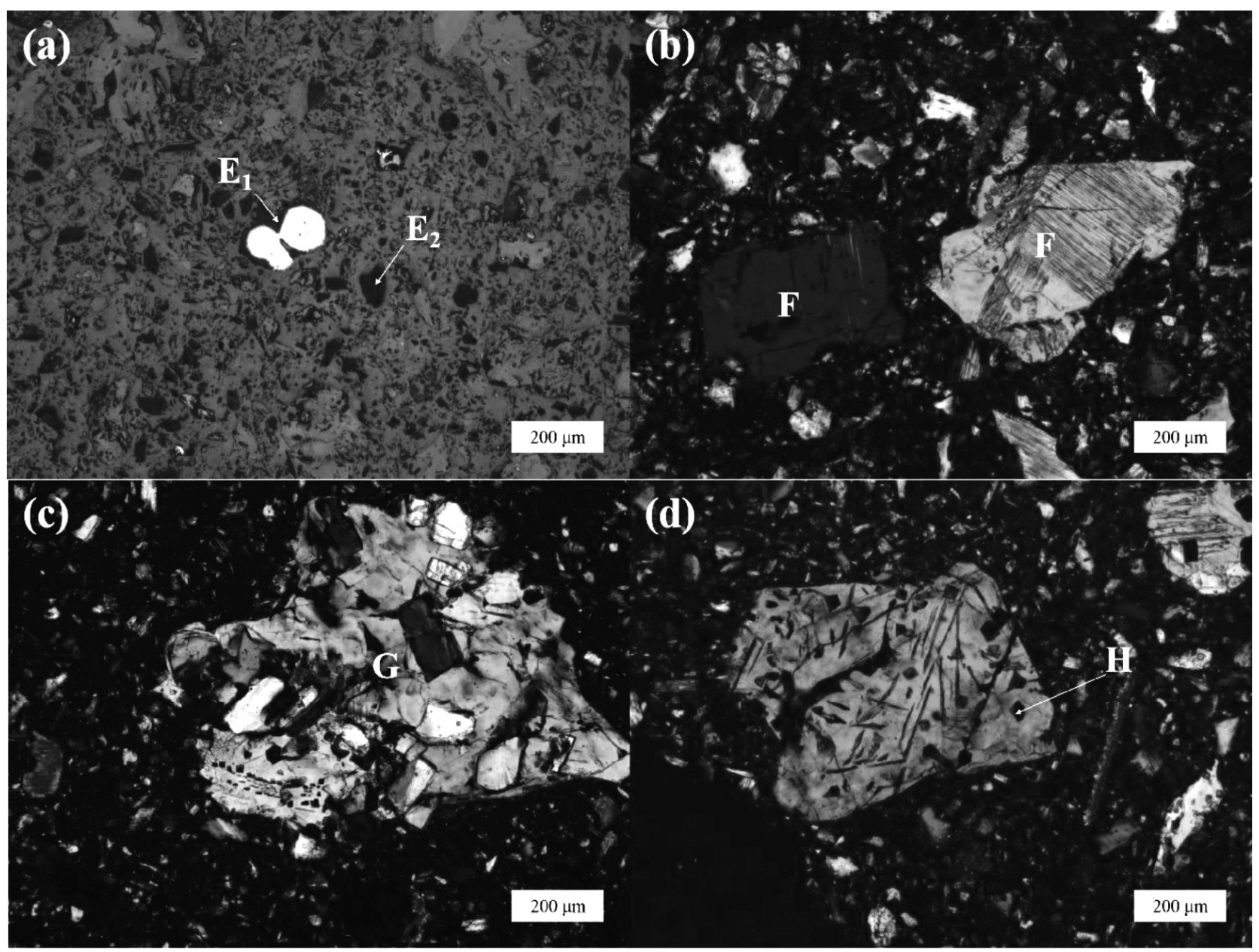

Figure 3: Microscopic structure of the natural leaching AOD slag: a) Fe and $\mathrm{C}_{2} \mathrm{~S}$ under reflected light, b) $\mathrm{C}_{3} \mathrm{MS} \mathrm{S}_{2}$ under transmitted light, c) $\mathrm{C}_{3} \mathrm{MS}_{2}$ under transmitted light, d) spinel under reflected light

Calcium ferrite and the glass and RO phases were distributed mainly in $\mathrm{C}_{2} \mathrm{~S}$.

\subsection{Dissemination characteristics of minerals after natural leaching}

The characteristics of the typical minerals in the neutral leaching residue are shown in Figure 3. The $\mathrm{C}_{2} \mathrm{~S}$ $\left(E_{2}\right)$ form changed from fine granular aggregates to shaped granular aggregates $(0.01 \mathrm{~mm}$ to $0.06 \mathrm{~mm})$ and from columns to fine needles and columns $(0.01 \times 0.03$ $\mathrm{mm}$ to $0.06 \times 0.15 \mathrm{~mm}$ ) compared with the form of the original slag. The particle size of $\mathrm{C}_{2} \mathrm{~S}$ in the neutral leaching residue was significantly smaller than that in the original slag. This difference occurred because during the neutral leaching process, the $\mathrm{C}_{2} \mathrm{~S}$ hydration reaction in the slag led to a fine $\mathrm{C}_{2} \mathrm{~S}$ morphology and decreased particle size. $\mathrm{C}_{3} \mathrm{MS}_{2}(\mathrm{~F}, \mathrm{G})$ mainly existed as granules $(0.03 \mathrm{~mm}$ to $0.26 \mathrm{~mm})$, spindles and columns, and the granules increased in size. This result was observed because $\mathrm{C}_{3} \mathrm{MS}_{2}$ was insoluble during the neutral leaching process, while the $\mathrm{C}_{2} \mathrm{~S}$ hydration product combined with $\mathrm{MgO}$ to generate $\mathrm{C}_{3} \mathrm{MS}_{2}$, resulting in coarse and very granular $\mathrm{C}_{3} \mathrm{MS}_{2}$.

Regarding the minerals with low volume percentages, rankinite existed mainly as crystals and small columns $(0.01 \mathrm{~mm}$ to $0.06 \mathrm{~mm})$. Pyroxene existed mainly as granules $(0.05 \mathrm{~mm}$ to $0.12 \mathrm{~mm})$. The spinel $(\mathrm{H})$ phase was partially wrapped in $\mathrm{C}_{3} \mathrm{MS}_{2}$ and existed mainly as squares and granules $(0.01 \mathrm{~mm}$ to $0.03 \mathrm{~mm})$. Magnetite existed mainly as granules $(0.01 \mathrm{~mm}$ to $0.07 \mathrm{~mm})$.

Figure 3a shows that $\mathrm{Fe}$ was not coated with $\mathrm{C}_{2} \mathrm{~S}$ and mostly existed in a monomeric form. This structure was due to the large amount of $\mathrm{C}_{2} \mathrm{~S}$ hydration during neutral leaching, which exposed the Fe contained in the $\mathrm{C}_{2} \mathrm{~S}$.

\subsection{Dissemination characteristics of minerals after acid leaching}

The characteristics of the typical minerals after acid.leaching residue are shown in Figure 4. $\mathrm{C}_{2} \mathrm{~S}\left(\mathrm{I}_{1}, \mathrm{I}_{2}\right)$ existed as short columns $(0.01 \mathrm{~mm}$ to $0.05 \mathrm{~mm})$ and fine granular aggregates $(0.01 \times 0.05 \mathrm{~mm}$ to $0.11 \times 0.2 \mathrm{~mm})$. Similar to that of the neutral leaching residue, the 


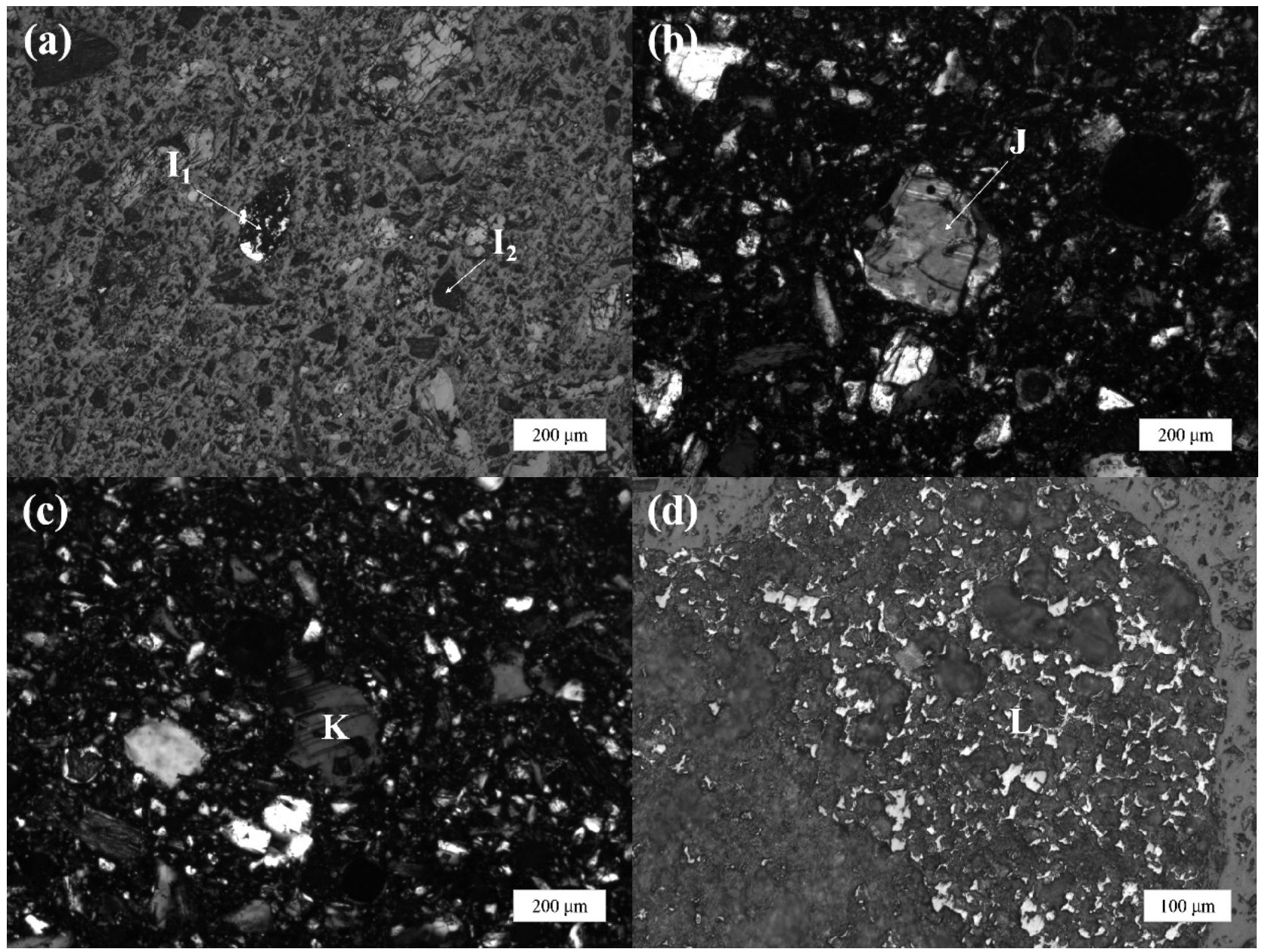

Figure 4: Microscopic structure of the acid.leaching AOD slag: a) Fe and $\mathrm{C}_{2} \mathrm{~S}$ under reflected light, b) $\mathrm{C}_{3} \mathrm{MS}_{2}$ under transmitted light, c) $\mathrm{C}_{3} \mathrm{MS} \mathrm{S}_{2}$ under transmitted light, d) complete slag under reflected light

particle size of $\mathrm{C}_{2} \mathrm{~S}$ in the acid-leaching residue was significantly smaller than that in the original slag. This difference occurred because during the acid-leaching process, the $\mathrm{C}_{2} \mathrm{~S}$ hydration reaction in the slag led to a fine $\mathrm{C}_{2} \mathrm{~S}$ morphology and small particle size. $\mathrm{C}_{3} \mathrm{MS}_{2}(\mathrm{~J}$, $\mathrm{K})$ mainly existed as granules and diamonds $(0.03 \mathrm{~mm}$ to $0.26 \mathrm{~mm})$. The granularity became larger than that in the original sample. This phenomenon occurred for the same reasons as those described in Section 2.4.

Rankinite existed mainly as crystals and short columns $(0.01 \mathrm{~mm}$ to $0.05 \mathrm{~mm})$. Pyroxene existed mainly as granules and short columns $(0.05 \mathrm{~mm}$ to $0.18 \mathrm{~mm})$. Magnetite existed mainly as crystals $(0.05 \mathrm{~mm}$ to $0.07 \mathrm{~mm})$.

Figure 4 reveals the same phenomenon as that observed during the neutral leaching process; Fe was not coated with $\mathrm{C}_{2} \mathrm{~S}$ and existed mainly as round grains and crystals. The reasons provided in Section 2.4 can explain this phenomenon perfectly.

Only one complete residue (L) was found in the sample. The main mineral compounds included $\mathrm{C}_{2} \mathrm{~S}$, the Golgi-rich phase, the glassy phase and the RO phase.
The RO phase was distributed in $\mathrm{C}_{2} \mathrm{~S}$, and the Golgi-rich phase was distributed in the glassy phase.

\subsection{Dissemination characteristics of minerals after alkaline leaching}

The characteristics of the typical minerals in the alkaline leaching residue are shown in Figure 5. The amount of $\mathrm{C}_{2} \mathrm{~S}(\mathrm{M}, \mathrm{P})$ in the alkaline leaching residue was significantly higher than that in the acid-leaching residue and natural leaching residue. $\mathrm{C}_{2} \mathrm{~S}$ mainly existed as granule aggregates $(0.02 \mathrm{~mm}$ to $0.5 \mathrm{~mm})$ and columns $(0.02 \times 0.03 \mathrm{~mm}$ to $0.05 \times 0.2 \mathrm{~mm})$. There was little difference in the $\mathrm{C}_{2} \mathrm{~S}$ volume percentage or form between the alkaline leaching residue and original slag. $\mathrm{C}_{3} \mathrm{MS}_{2}(\mathrm{~N})$ existed mainly as granules, small spindles, and short columns with particle sizes between $0.02 \mathrm{~mm}$ and 0.45 $\mathrm{mm}$. Since the $\mathrm{OH}^{-}$in the alkaline leaching solution had an inhibitory effect on the hydration of $\mathrm{C}_{2} \mathrm{~S}$, the relative amounts of the main mineral phases did not change greatly.

Rankinite mainly existed as small columns and granules $(0.02$ to $0.11 \mathrm{~mm})$. Pyroxene mainly existed as 


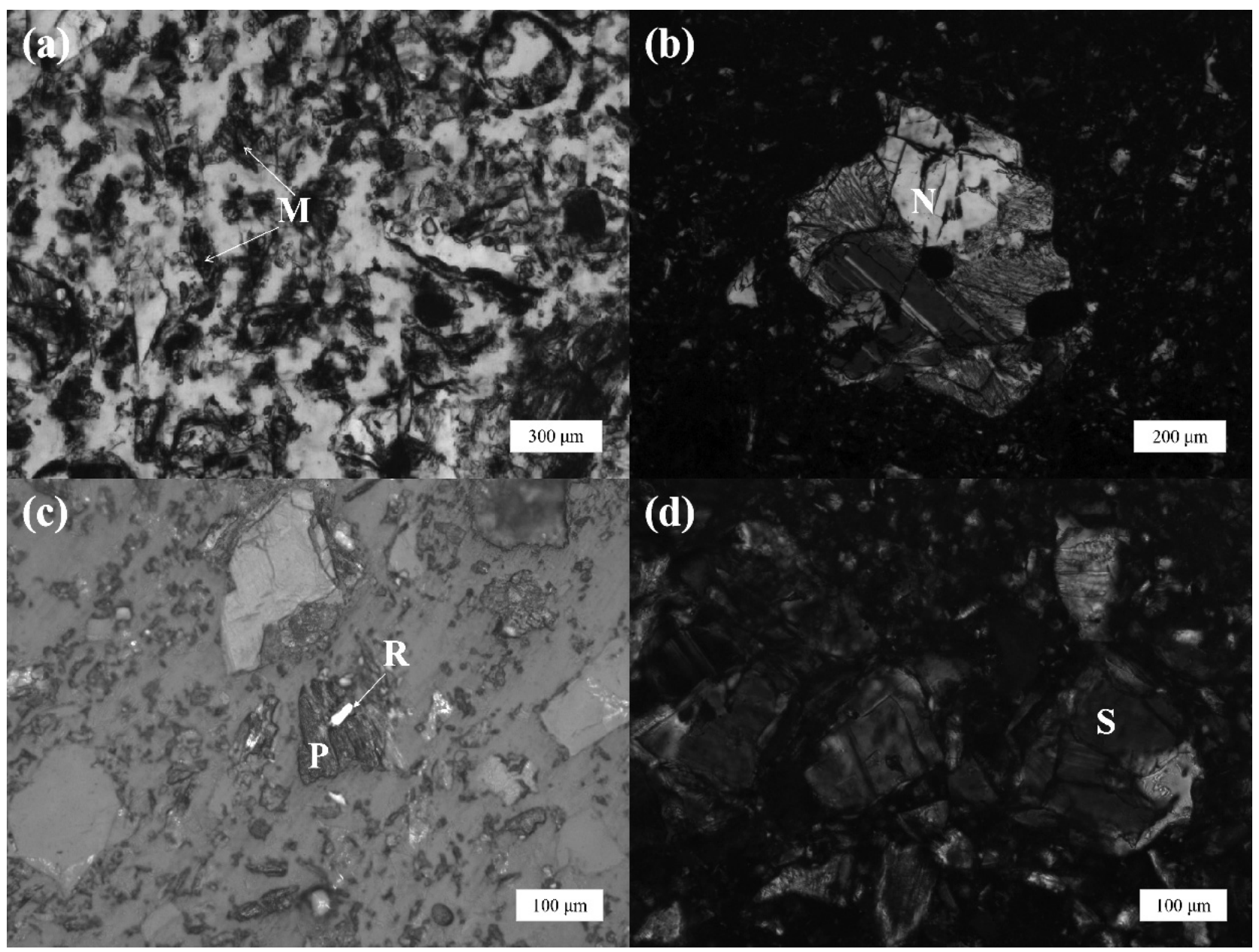

Figure 5: Microscopic structure of the alkaline leaching AOD slag: a) $\mathrm{C}_{2} \mathrm{~S}$ under reflected light, b) $\mathrm{C}_{3} \mathrm{MS}_{2}$ under transmitted light, c) Fe and $\mathrm{C}_{2} \mathrm{~S}$ under reflected light, d) pyroxene under transmitted light

granules $(0.03 \mathrm{~mm}$ to $0.12 \mathrm{~mm})$. Magnetite mainly existed as granules, and a small amount was observed.

Unlike the neutral leaching and acid-leaching cases, Fe was mostly distributed in $\mathrm{C}_{2} \mathrm{~S}$ after alkaline leaching and partially distributed in magnetite. Fe (R) existed mainly as round grains $(0.005 \mathrm{~mm}$ to $0.05 \mathrm{~mm})$. As shown in Table 1 , the amount of $\mathrm{C}_{2} \mathrm{~S}$ in the alkaline leaching residue did not decrease and retained a predominant volume ratio, so $\mathrm{Fe}$ continued to be coated with $\mathrm{C}_{2} \mathrm{~S}$.

A comparison of the microstructure and dissemination characteristics of the main minerals in the original slag and 3 types of leaching residues reveals that the average particle sizes of $\mathrm{C}_{2} \mathrm{~S}, \mathrm{C}_{3} \mathrm{MS}_{2}$, rankinite, and pyroxene in the leaching residues changed greatly. This change in particle size occurred because the volume percentage of the mineral phases changed greatly: as one parameter decreased, the other increased.

There was no change in the volume percentage of Fe, but its dissemination characteristics changed, and $\mathrm{Fe}$ was no longer mostly covered in $\mathrm{C}_{2} \mathrm{~S}$ in the natural leaching residue and acid.leaching residue. This result indicates that because $\mathrm{C}_{2} \mathrm{~S}$ had the greatest volume percentage, it covered other minerals, such as Fe. When the AOD slag underwent natural or acid leaching, its $\mathrm{C}_{2} \mathrm{~S}$ phase content was reduced because of hydrolysis, exposing $\mathrm{Fe}$.

\section{CONCLUSIONS}

The main mineral phases in the AOD slag were $\mathrm{C}_{2} \mathrm{~S}$, $\mathrm{C}_{3} \mathrm{MS}_{2}$, rankinite, and pyroxene. The minor mineral phases in the AOD slag were spinel, magnetite, the Golgi-rich phase, the glass phase, the RO phase, and calcium ferrite.

After neutral and acid leaching, although the number of mineral species did not change, the volume percentage of each mineral changed greatly. The content of $\mathrm{C}_{2} \mathrm{~S}$ decreased sharply due to hydrolysis. Because of the insolubility of $\mathrm{C}_{3} \mathrm{MS}_{2}$, the hydration products of $\mathrm{C}_{2} \mathrm{~S}$ and free $\mathrm{MgO}$ combined to significantly increase the content of $\mathrm{C}_{3} \mathrm{MS}_{2}$.

After neutral and acid leaching, the microstructures and dissemination characteristics of the major mineral phases in the AOD slag changed greatly. The average 
particle size of $\mathrm{C}_{2} \mathrm{~S}$ decreased, while that of $\mathrm{C}_{3} \mathrm{MS}_{2}$ increased. Due to $\mathrm{C}_{2} \mathrm{~S}$ hydration, $\mathrm{C}_{2} \mathrm{~S}$ changed from aggregates into short columns and fine granules, and $\mathrm{C}_{3} \mathrm{MS}_{2}$ grew from very small spindles and short columns into larger spindles and columns, respectively. The $\mathrm{Fe}$ was no longer coated with $\mathrm{C}_{2} \mathrm{~S}$ and existed mainly in its monomeric form.

After alkaline leaching, the volume percentage of each mineral changed little. The $\mathrm{C}_{2} \mathrm{~S}$ content increased by $5 \%$, the pyroxene and rankinite contents decreased by $1 \%$ and $3 \%$, respectively, and the $\mathrm{C}_{3} \mathrm{MS}_{2}$ content remained almost unchanged. The average particle size of $\mathrm{C}_{2} \mathrm{~S}$ became coarser than that in the original slag. The reason for the observed results is that $\mathrm{OH}^{-}$had an inhibitory effect on the hydration of $\mathrm{C}_{2} \mathrm{~S}$ and even reversed the hydration reaction.

\section{Acknowledgments}

The authors gratefully acknowledge support from the National Natural Science Foundation of China (No. 51574108).

\section{REFERENCES}

${ }^{1}$ http://www.cssc.org.cn/page137?article_id=1433, Stainless steel council of China special steel enterprises association, 28.1.2019

${ }^{2}$ H. Zhao, Y. Qi, Y. Shi, X. Na, H. Feng, Mechanism and prevention of disintegration of AOD stainless steel slag, Journal of Iron and Steel Research, International, 20 (2013) 4, 26-30, doi:0.1016/ S1006-706X(13)60078-3

${ }^{3}$ S. Zhang, Y. Zhang, Z. Qu, Physicochemical property and chromium leaching behavior indifferent environments of glass ceramics prepared from AOD stainlesssteel slag, Journal of Alloys and Compounds, 805 (2019) 1106-1116, doi:10.1016/j.jallcom.2019. 07.065

${ }^{4}$ Q. Zhao, C. Liu, L. Cao, X. Zheng, M. Jiang, Stability of chromium in stainless steel slag during cooling, Minerals, 8 (2018) 10, 445, doi: $10.3390 / \mathrm{min} 8100445$

${ }^{5}$ F. Engström, D. Adolfsson, C. Samuelsson, A. Sandström, B. Björkman, A study of the solubility of pure slag minerals, Mineral Engineering, 41 (2013). 46-52, doi:10.1016/j.mineng.2012.10.004

${ }^{6}$ H. Shen, E. Forssberg, U. Nordström, Physicochemical and mineralogical properties of stainless steel slags oriented to metal recovery, Resources Conservation and Recycling, 40 (2004), 245-271, doi:10.1016/S0921-3449(03)00072-7

${ }^{7}$ D. X. Wei, A. J. Xu, D. F. Dong, N. Y. Tian, Q. X. Yang, Beneficial reuse of EAF slag and its leaching behavior of Cr, Iron Steel, 47 (2012), 92-96, (In Chinese with English abstract), doi:10.1007/s11783-011-0280-Z

${ }^{8}$ H. Z. Shi, R. Y. Wang, R. H. Chen, L. Shi, Safety analysis of stainless steel slag used as composite cement admixture, Journal of Building Materials, 13 (2010), 802-806, (In Chinese with English abstract), doi:10.1360/972010-1322

${ }^{9}$ C. L. Zhen, Z. X. Na, Y. H. K. Qi, Zhao, Y. Lv, Study on leaching behavior of chromium in EAF slag and risk analysis of beneficial reuse, Environmental Engineering, 30 (2012), 93-95, (In Chinese with English abstract)
${ }^{10}$ N. Panichev, W. Mabasa, P. Ngobeni, K. Mandiwana, S. Panicheva, The oxidation of $\mathrm{Cr}(\mathrm{III})$ to $\mathrm{Cr}(\mathrm{VI})$ in the environment by atmospheric oxygen during the bush fires, Journal of Hazardous Materials, 153 (2008) 3, 937-941, doi:10.1016/j.jhazmat.2007.09.044

${ }^{11}$ A. D. Apte, V. Tare, P. Bose, Extent of oxidation of $\mathrm{Cr}$ (III) to $\mathrm{Cr}(\mathrm{VI})$ under various conditions pertaining to natural environment, Journal of Hazardous Materials, 128 (2006) 2-3, 164-174, doi:10.1016/ j.jhazmat.2005.07.057

${ }^{12}$ K. Pillay, H. Blottnitz, J. Petersen, Aging of chromium(III)-bearing slag and its relation to the atmospheric oxidation of solid chromium(III)-oxide in the presence of calcium oxide, Chemosphere, 52 (2003), 1771-1779, doi:10.1016/S0045-6535(03)00453-3

${ }^{13}$ L. D. Thomas, C. Max, Mechanisms of chromium-induced toxicity, Current opinion in toxicology, 14 (2019), 1-7, doi:10.1016/j.cotox. 2019.05.003

${ }^{14}$ Q. Shu, Q. Luo, L. Wang, K. Chou, Effects of $\mathrm{MnO}$ and $\mathrm{CaO} / \mathrm{SiO}_{2}$ mass ratio on phase formations of $\mathrm{CaO}-\mathrm{Al}_{2} \mathrm{O}_{3}-\mathrm{MgO}-\mathrm{SiO}_{2}-\mathrm{CrO}_{\mathrm{x}} \mathrm{Slag}$ at $1673 \mathrm{~K}$ and $P_{\mathrm{O} 2}=10^{-10} \mathrm{~atm}$, Steel Research International, 86 (2015) 4, 391-399, doi:10.1002/srin.201400117

${ }^{15}$ L. H. Cao, C. J. Liu, Q. Zhao, M. F. Jiang, Effect of $\mathrm{Al}_{2} \mathrm{O}_{3}$, modification on enrichment and stabilization of chromium in stainless steel slag, Journal of Iron and Steel Research, International, 24 (2017) 3, 258-265, doi:10.1016/S1006-706X(17)30038-9

${ }^{16}$ Y. Samada, T. Miki, M. Hino, Prevention of chromium elution from stainless steel slag into seawater, ISIJ International, 51 (2011) 5 , 728-732, doi:10.2355/isijinternational.51.728

${ }^{17}$ G. Adegoloye, A. L. Beaucour, S. Ortola, A. Noumowe, Concretes made of EAF slag and AOD slag aggregates from stainless steel process: mechanical properties and durability, Construction and Building Materials, 76 (2015), 313-321, doi:10.1016/j.conbuildmat. 2014.12.007

${ }^{18}$ L. H. Cao, C. J. Liu, Q. Zhao, M. F. Jiang, Analysis on the stability of chromium in mineral phases in stainless steel slag, Metallurgical Research \& Technology, 115 (2018) 1, 114, doi:10.1051/metal/ 2017071

${ }^{19}$ M. Kuhn, D. Mudersbach, Treatment of liquid EAF-slag from stainless steelmaking to produce environmental friendly construction materials, Proceedings of the $2^{\text {nd }}$ international conference on process development in iron and steelmaking, 2004

${ }^{20}$ Q. Wang, P. Y. Yan, J. W. Feng, A discussion on improving hydration activity of steel slag by altering its mineral compositions, Journal of Hazardous Materials, 186 (2011) 2-3, 1070-1075, doi:10.1016/ j.jhazmat.2010.11.109

${ }^{21}$ J. G. Li, B. Liu, Y. N. Zeng, Maximum availability and mineralogical control of chromium released from AOD slag, Environmental Monitoring and Assessment, 189 (2017) 3, 113, doi:10.1007/ s10661-017-5843-4

${ }^{22}$ Y. J. Wang, J. G. Li, N. Zheng, Mineral compositions and microstructures of AOD stainless steel slag, Iron Steel Vanadium Titanium, 34 (2013) 4, 68-72, (In Chinese with English abstract), doi:10.7513/j.issn.1004-7638.2013.04.013

${ }^{23}$ B. Liu, J. G. Li, Y. N. Zeng, Z. M. Wang, Toxicity assessment and geochemical model of chromium leaching from AOD slag, Chemosphere, 144 (2016), 2052-2057, doi:10.1016/j.chemosphere. 2015.10.103

${ }^{24}$ J. G. Li, B. Liu, Y. N. Zeng, Z. M. Wang, Mineralogical determination and geo-chemical modeling of chromium release from AOD slag: Distribution and leachability aspects, Chemosphere, 167 (2017), 360-366, doi:10.1016/j.chemosphere.2016.10.020

${ }^{25}$ C. L. Zhen, X. Z. Na, Y. H. Qi, Y. Lv, Basic research of stainless steel slag property and risk assessment on resource reclamation, Steelmaking, 28 (2012) 4, 74-77, (In Chinese with English abstract) 